\title{
The Impact of Financialization and Strategy
}

\author{
Shengnan Zheng \\ Business School \\ Sichuan University \\ Chengdu, P.R.China
}

\author{
Qi Chen \\ Business School \\ Sichuan University \\ Chengdu, P.R.China
}

\author{
Shengdao Gan \\ Business School \\ Sichuan University \\ Chengdu, P.R.China
}

\begin{abstract}
Financialization has become the basic economic characteristics. Moderate financialization will help enterprises to ease the financing constraints, providing power to the main business. However, excessive financialization will have an impact on the real economy and financial institutions. This paper analyzes the causes and effects of the financialization and explores the countermeasures of over- financialization.
\end{abstract}

Keywords-financialization; real economy; capital market; industrial capital

\section{INTRODUCTION}

With the weak demand of the real economy and the persistence of excess capacity, financialization has become the basic economic feature. As for the definition of financialization, there is no unified point of view in academia. The theoretical and practical circles have made different interpretations of the meaning of financialization from different perspectives.

Arrighi interpreted financialization as a result of the competition between capital and between countries in the power transition stage [1]. The profit was thought to be mainly generated through financial channels rather than the field of production and trade. From the perspectives of productivity, Zhao lei and Xiao bin believe that the social division of labor produced the financial industry, which is mainly from the independent and professional operation of loan capital and money-dealing capital [2]. These interpretations emphasize the cyclical nature of the changes in the capitalist system from the perspective of the distribution of power and class struggle. They consider the financialization as a process of financial expropriation by "raiders". Thomas Palley argues that financialization is a process in which capital markets, financial institutions and financial elites have increased their influence on economic policy and economic benefits [3]. This process has led to an increase in the status of the financial sector, the transfer of wealth and income from the physical sector to the financial sector, and also in equality. To some extent, this interpretation focuses on the macroeconomic capital allocation, focusing on the strength contrast between financial capital and industrial capital. It takes into account the advantages of financial assets in total assets. But the question is how to distinguish industrial capital from financial capital. At the same time, this definition only stays on the description of the phenomenon, thus lacking analysis of the nature behind the phenomenon.

At the micro level, Julie Froud and Colin Haslam argue that financialization means a new form of competition in which capitalist market forces are able to respond to retailers and consumers' product markets in a comprehensive and rapid manner through investment institutions and professional fund managers [4]. Meanwhile, the financialization of non-financial companies refers to the nonfinancial companies to allocate their resources to financial assets outside of production and business activities to divide the profits of the financial industry.

\section{REASONS AND CURRENT SitUATION OF CNINA'S FINANCIALIZATION}

\section{A. The Macroeconomic Volatility}

Under the pressure of economic downturn, demand is weak and capacity is relatively excess, increasing market volatility and uncertainty increased the volatility of market prices. Yang Mingii's research shows that resource prices affect the profitability of enterprises by influencing the profit situation of enterprises, but also affect the allocation of credit funds [5]. The development of non-financial listed companies faces more challenges. Some enterprises have the capital "unrealistic" tendencies in response to the potential risk of systemic reform. In addition, the exchange rate fluctuations and the uncertainty of inflation to a certain extent encouraged the non-financial industry listed companies financial investment behavior.

\section{B. Development and Innovation of Capital Markets}

With the slowdown in the growth of traditional financial services, property rights reform has stimulated the reform of small and medium-sized financial institutions. The rapid rise of Internet finance and Pratt \& Whitney Finance, the 
innovation of financial instruments, the lifting of capital controls, the development of information technology - shortterm capital flows into capital markets, forming a huge arbitrage space - an important force of financialization.

\section{Crowding out Effect of Capital}

Relative to the industrial capital, financial capital does not directly rely on their own production and business activities to obtain profits. It obtains profits through a certain mode of operation, relying on the sale of financial products in order to obtain business income. Crotty's empirical study [6] shows that the proportion of US financial firms' profits higher than those of non-financial companies rose from $15 \%$ in the 1950 s and 1960 s to $50 \%$ in 2001 . During this period, the portfolio gains from nonfinancial enterprises and cash flow ratio also rose from $14 \%$ to $37 \%$. It indicates that in the face of two options between physical investment and financial investment, non-financial listed companies not only depends on the expected rate of return on investment projects, but also considers the capital of the profit squeeze. Orhangazi found that there was a negative correlation between real investment and financialization by studying the impact of financialization on the actual capital accumulation of US non-financial companies [7]. In other words, the rigidity of capital and the uncertainty of the market lead to investment decision-making behavior of companies, and the crowding out effect of capital further promotes investors to choose short-term reversible financial investment and abandon the long-term fixed investment with uncertain risk.

\section{THE IMPACT AND THE ROLE OF FINANCIALIZATION}

With the growth of international capital market and the increasing trend of financialization, the competition between financial institutions has also changed fundamentally. In particular, the innovation of financial products has changed the financial institutions from resource exploration in the past to the competition of internal management and innovation, resulting in the financial institutions of the management has undergone profound changes. In addition, corporations are increasingly governed by the diktats of capital markets.

\section{A. Changes in Basic Economic Structure}

Both in theory and practice, there is still full of uncertainty about the financial and financial itself and its possible changes in the basic economic structure. And the complexity of China's economic reality is more confusing. The financialization is actively promoting the prosperity and the development of the capital market, at the same time it increase the dependence of the financial capital [8]. Enterprises use their internal funds to increase financial investment, producing a crowding out effect on the real economy; weak real economy, the absence of strength of the capital market, the lack of rational allocation of market factors - trigger the capital market disorder further and form the vicious cycle. In terms of structure, although the total amount of financial assets increased rapidly, but the structural changes are still slow. In recent years the proportion of financial institutions' asset returns has rised, the stock value decline now and then.

\section{B. Economic Risk Expansion}

In the role of financialization, economic risk has a trendency to rapid expansion. Orhangazi's research found a negative relationship between financialization and real investment. Since the company's managers could change the incentive and the direct internal accumulation model of the real investment, the increased financial investment and profit opportunities will have a crowding out effect on the real investment. Reducing the proportion of the internal accumulation fund can hamper the company's real investment, for it reduce the manager's planning period and increase uncertainty, as well as an increase in capital market returns and payments. Zhang Chen and Feng Zhixuan pointed out that is difficult to recover the real economic profit rate represented by the manufacturing industry, which make the capital investment led to the pursuit of higher profit margins and cannot flow to the manufacturing sector but only circulate in the financial sector [9]. Moreover, manufacturing companies are mostly booked from the financial sector rather than the manufacturing industry itself. The continued downturn in the real economy makes it difficult to create sufficient employment, and the highly capital-intensive nature of the financial sector in the "raiders" model has resulted in a serious polarization in the labor market.

\section{The Transformation of Bank Roles}

The development of investment banking has shifted banks to capital market intermediaries. Two fundamental trends have inspired the functions of commercial banks to implement investment banks since the late 1970s - the first one is the continuous merger and acquisition between the companies, the second is the savings of workers and others lead to capital markets through national policies [10]. In recent years, the stock market has not been an important source of financing for fixed investment, but they have clearly contributed to the accumulation and concentration of capital through similar transactions such as initial public offerings and leveraged acquisitions. In the United States, pension deposits can be used for stock market investment. In the UK, individual equity participation, personal savings accounts, tax-free special deposit accounts are the financialization of personal income. It is the key to transformation of bank roles that how to make financial capital more effective for economic activities to provide basic support through the capital market.

\section{The Positive Effects}

Although the financial economy itself is full of risks, but cannot deny the basic functions of the financial system to disperse, transfer and manage risk. The major banks, securities companies and other financial institutions in developed countries are actively involved in the innovation and transaction of financial products, making financial risk management become the foundation and core of modern financial institutions [11]. There appears a lot of financial 
services intermediaries such as commercial banks, insurance companies, investment funds, accounting firms, audit firms, law firms and credit rating agencies. The emergence and development of almost all financial institutions and risk management have a direct and indirect causal relationship. There is a variety of available options of risk - income structure of financial instruments. The financial system allocates risk rationally to those economic subjects responsible and willing to undertake on the platform of financial intermediaries, financial instruments and capital markets.

Therefore, financialization changes the proportion relationship between the financial economy and the real economy. At the same time, financialization is likely to not only improve the macroeconomic and microeconomic risk level, but also enhance the financial risk management functions.

\section{RESPONSE STRATEGIES TO OVER-FINANCIALIZATION}

Over-financialization has changed the governance structure of companies to a certain extent. Enterprises use their internal funds to increase investment in capital markets, transfering the external risks into internal risks and shortening the capital cycle of enterprises. On the impact of the real economy and financial institutions, an increase of market risk and the non-controllability, its diversified development may lead to capital market instability. Low financial asset return rate comes with the inefficient use of financial capital. Meanwhile, a large number of capital accumulate in the capital market, which has formed investment resistance on the real economy dependent on the production and consumption, resulting in the downturn of the real economy in the status quo.

\section{A. Open Capital Markets and Broaden the Channels of Capital Flows}

Amit Bhaduri pointed out that while the financialization promotes the prosperity and development of the capital market actively, it makes the dependence on financial capital increase [12]. This means that in the process of overfinancialization management, it is necessary to ensure not only the capital adequacy but also to broaden the channel of leading the capital to invest. China's capital market needs to be improved. Companies face multiple difficulties at the moment, especially for non-financial private listed companies, the urgent need for which is legal and policy support to solve their own financing constraints and seeking a mature investment model. Wang Fang believes that the domestic formal financial supply of funds cannot meet the private sector funding needs effectively as a whole. It require to establish an open, multi-level capital markets and broaden the channels of capital flows, only in this way can the private enterprise get out of economic development bottlenecks. Capital market could relax access conditions from the source to ensure the demand for funds to ease companies' financing pressure as well as the financial capital provide basic support for economic activities more effectively.

\section{B. Strengthen Financial Supervision and Standardize Financial Behavior}

The whole financial system will be more fragile, when companies get down to avoiding risks and strengthening the safety of capital. China's companies exist management Insider control and the high cost of agency issues exist in China's companies widely. The management use of its information advantages to invest the enterprise's free cash flow in the project of short-term gains, gradually forming a governance structure and incentive mechanism which prefer short-term return rather than long-term steady development, so that eroding the interests of shareholders.

In the view, the company's shareholders can proceed from two aspects to reduce the agency costs [13]. One thing is to improve the corporate governance mechanism to improve the efficiency of internal control. The other thing is to rely on external capital market, that is, debt and mergers \& acquisitions. As China's capital market does not develop maturely at the current stage and the economic structure is still in transition, the government and regulatory authorities should be vigilant of the high concentration of financial capital to avoid "follow the trend" investment and blind cross-border restructuring, to reduce the financial phenomenon caused by speculative motives, to avoid the trend of business risk expansion to ensure that the financial capital and industrial capital in the dynamic balance. Only to take advantages of financial regulatory can minimize the damage caused by capital market flaws to the high degree of linkage of the financial system, which could regulate the financial behavior of listed companies to encourage them to strengthen internal supervision and to avoid managers surplus manipulation further.

\section{Financial Integration and Develop Real Economy}

Increased financial investment opportunities and rich financial profits make enterprises more use of internal funds to increase investment in capital markets, making the outcrowding effect on the real economy. Lack of reasonable allocation of market elements comes with the weak real economic demand, leading to the disruption of capital markets and even the formation of a vicious circle. Therefore, while coordinating the contradiction of supply and demand, it becomes a top priority to prevent the problem of hollow industry. William Milberg believes that the financialization makes enterprises reduce its business to the core areas of competence, thus encouraging the adjustment of production structure [14]. This is also the direction and goal of financial reform.

On the one hand, the capital market should strengthen the combination of industry and financial strength, and further develop the property rights trading market to cultivate listed companies to resist financial risks. Enterprise financialization would be more efficient through allocating the financial capital scientificly after guiding enterprises to understand the relation between high return and high risk of financial capital correctly. On the other hand, it is necessary to revitalize the real economy and strengthen long-term macro-control. Enterprises should correct its speculation and establish innovative mechanisms. For potential investors, 
providing more favorable employment policy is a good way to improve the efficiency of capital use. Only to curb the expansion of monopoly behavior in the market actively, it would promote the industrial structure transformation and upgrading, thus maintain the smooth operation of the economy.

\section{CONCLUSION}

Financializations perform for which the economy is focus on the finance and dominate the accumulation and the growth system of real economy, reflecting a major social and economic transformation at the current. In the process of financialization, the status of the financial capital and industrial capital have a systematic change in the economic operation, the core of this change is the transformation from capital structure to the financialization, so that the financial capital can achieve a control of production of real economy comprehensively and effectively. As financial capital penetrates into the industrial sector, the financing of the nonfinancial sector is also expanding and incorporated into the financial system. The financialization involves the corporate governance of the shareholder value-oriented, the accumulation model of the transfer of the capital entity economy into the financial field, the diversified investment economic risk, and the reform of the financial institutions. The research on the reasons and consequences of the financialization have significant implications for China at present for which is in the context of supply-side reform.

\section{REFERENCES}

[1] Giovanni Arrighi, The Long Twentieth Century, 3rd ed. Nanjing: Jiangsu People's Publishing House, 2001.

[2] Zhao Lei, Xiao Bin, "How financialization can be - a marxist interpretation," Contemporary Economic Research, vol. 3, pp. 61-65, 2013.

[3] Thomas, I, Palley, "Financialization: What It Is and Why It Matters," Working Paper, vol. 12, 2007.

[4] Julie Froud, Colin Haslam, Sukhdev Johal, Karel Williams , "Shareholder Value and Fiancialization: Consultancy Promises, Management Moves," Economy and Society, vol. 29, pp. 80-110, 2000.

[5] Yang Mingji, "The Empirical Effect of Resource Price on Economy and Finance - Taking Gansu as an Example," Journal of Financial Research, vol. 12, 2006.

[6] James Crotty, "The Neoliberal Paradox: The Impact of Destructive Product Market Competition and Impatient Finance on Nonfinancial Corporations in the Neoliberal Era," Review of Radical Political Economics, vol. 35, pp. 271-279, 2003.

[7] Özgür, Orhangazi, "Financialisation and Capital Accumulation in the Non-financial Corporate Sector : A Theoretical and Empirical Investigation on the US Economy: 1973-2003," Cambridge Journal of Economics, vol. 32, pp. 863-886, 2008.

[8] Amit Bhaduri, "A Contribution to the Theory of Financial Fragility and Crisis," Cambridge Journal of Economics, vol. 35, pp. 995-1014, 2011.

[9] Zhang Chen, Feng Zhixuan, "Reindustrialization or Financialization," China Review of Political Economy, vol. 7, pp. 171-189, 2016.

[10] Lapavitsas.C., "The Financial Capitalism: Crisis and Financial Expropriation," China Review of Political Economy, vol. 1, pp. 3058, 2009.
[11] Wang Fang, "The Financializaton and Economic Structure Reform," Journal of Financial Research, vol. 8, 2004

[12] Amit Bhaduri, "A Contribution to the Theory of Financial Fragility and Crisis," Cambridge Journal of Economics, vol. 35, pp. 995-1014, 2011.

[13] Huang Benduo, Gan Shengdao, "Equity Check-and-balances, Free Cash Flow and Overinvestment Research," Commercial Research, vol. $9,2009$.

[14] William Milberg, "Shifting sources and uses of profits: sustaining US financialization with global value chains," Economy and Society, vol. 37, pp. 420-451, 2008 